\title{
Barriers To Effective Supply Chain Management, Implementation, And Impact On Business Performance Of SMEs In South Africa
}

Job Dubihlela, Vaal University of Technology, South Africa

Osayuwamen Omoruyi, Vaal University of Technology, South Africa

\begin{abstract}
Supply chain management (SCM) is vital for companies to achieve their goals and for information sharing. Operations managers are faced with many barriers in implementing SCM, particularly in developing economies such as South Africa. It is essential for managers of SMEs to know the key barriers and attempt to minimize them and improve competitive strength. This article presents the SCM implementation barriers and suggests significant variations between these barriers as well as their impact on the business performance of SMEs. Researchers and trained fieldworkers gathered the needed data through face-to-face interviews using structured questionnaires, obtaining a total of 249 usable questionnaires. The data analysis included frequencies, confirmatory factor analysis (CFA) in Amos 5, and structural equation modelling (SEM) run LISREL 8.8. The results revealed that the lack of economies of scale, poor organisation structures, and technological challenges are the major limitations to implementing SCM. The findings of this research provide invaluable information to scholars and researchers investigating the barriers of SCM implementation, and to SMEs managers who desire to implement SCM. The findings can assist the development of effective strategic and operational plans as well as to programs and projects designed to enhance SCM within SMEs in South Africa. The research paper concludes by discussing both academic and managerial implications of the results, providing future research directions.
\end{abstract}

Keywords: Supply Chain Management; SMEs; Implementation Barriers; Business Performance; South Africa

\section{INTRODUCTION}

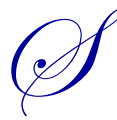

mall and medium-sized firms contribute strongly to the development of new ideas and technologies which drive the growth of new industries (Perks \& Bouncken, 2004). Although management and owners of SMEs develop new ideas and solutions, they are still faced with challenges as they rarely employ formal business objectives within their operations. These challenges are also apparent with the operational supply chain for various SMEs. According to Kisalvi (2002), dynamics and formation of strategic logistical activities and supply chain initiatives are directly connected to the SME managers' or owners' background and history.

Robbins and Coulter (2005) provides that SMEs gather information, identify potential opportunities, and pinpoint possible competitive advantages. With the information and the opportunities, SMEs begin to project operational feasibility and uncover business ideas, taking into account competitors and exploring financial options. SMEs proceed to further pursue their operational success and supply chain effectiveness (Burns, 2005). These activities include developing a viable organisational mission, exploring organisational culture issues like transportation, procurement, and supply chain, and creating a well thought-out business plan (Kotler, 1997). Therefore, the need to survive and grow, forces the SMEs to focus and qualify their performance, their investment, their strategic planning forecasts, and their supply chain strategy (Halley \& Guilhon, 1997). 
The benefits of enterprise-wide supply chain management have been widely promoted with often-cited examples such as Wal-Mart and Benetton. Supply chain can indeed be a true core competence, strategically positioning the organisation for market success and a source of long-run competitive advantage (Drew \& Smith, 1998). Supply chain strategies and strategic objectives, which result from changing customer needs, may pose some challenges as SMEs may have to redesign their business process and a total supply chain viewpoint (Drew \& Smith, 1998). SMEs often face some challenges trying to put into operation those value added strategies that may contribute positively towards the overall set of organisational goals. Recognising these challenging activities in supply chain is important as it helps SMEs to further improve on their business performance and their service delivery.

Supply chain processes over a number of years have also been an important component of business strategy that can provide a basis for a competitive profit edge through transportation and distribution activities (Agapiou, Clausen, Flanagan, \& Norman, 1998). Nevertheless, supply chain is still far from being an out-dated strategy, as companies realise it is not only a way to differentiate from competitors, but also a strategy factor in maximising the value chain (Lasserre, 2004). Supply chain can provide important information on decisions about transportation modes, efficient transportation choice within the mode, packaging impact as well as product delivery in a good condition. Supply chain has become a source of competitive advantage, especially after transportation deregulation and improvements in information technology that have enabled companies to gain competitive advantage through competence in speed delivery of customer orders, reliability, flexibility/responsiveness to changing market demands, and low-cost distribution (Van der vorst, Beulens, \& Van Beek, 2005; Zacharia \& Mentzer, 2007). Therefore, supply chain plays a strategic role in both large and small enterprises (Levey \& Powell, 2005). SMEs business objectives can survive competitive rivals such as (new requests from customers, on-going improvement in internal processes, and re-evaluation of company strategies) if supply chain strategies are implemented. SMEs should seek to optimise every stage of the supply chain to maximum value and optimise the operation of the supply chain as a whole in areas such as product delivery time, inventory holding cost, and the overall cost-to-market (Mason, Ribera, Farris, \& Kirk, 2003).

SMEs planning to build a corporate perspective of the future without recognising the importance of supply chain as a strategic focus may, lead merely to wishful thinking. This may create a barrier for the improvement of business performance (Drew \& Smith, 1998).

\section{IMPLEMENTATION OF SUPPLY CHAIN MANAGEMENT}

Information and communication technologies are important supply chain strategies to gain and maintain customer loyalty and to successfully implement strategic supply chain plans (Li \& Lin, 2006). SMEs' long-term growth and continuity depend on the ability to cope effectively with surprises and radical changes in supply chain technology (Jesselyn, 2006). Therefore, to consider how to improve the quality of supply chain service without considering the impact of information technology would be to omit from the theoretical framework one of the most important tools for controlling consistency, improving efficiency, improving supply chain operations, facilitating collaboration among suppliers, promoting effective decision-making, and allowing for the automation of many routing supply chain activities that modern business has at its disposal (Chow \& Lui, 2001; Bienstock, Royne, Sherrell, \& Stafford, 2007; Saura, Frances, Contri, \& Blasco, 2008).

SMEs need to put more emphasis on adopting changes in technology and on applying the appropriate level of technology to develop new products (Chan, Burns, \& Yung, 2000). Examples of supply chain technology that enhance quality and customer satisfaction are financial/accounting, e-mail, E-commerce (internet based), telephone and fax, E-suppliers, Electronic data interchange (EDI), Bar-coding, warehouse management system (WMS), performance measures, distribution resource planning (DRP), automated storage/retrieval system (AS/RS), vehicle routing/scheduling, and fibre optics communications technology.

Increasing ability to deliver an order on time, increasing operational efficiency, reducing inventory levels, increasing ability to reduce delivery lead time, skills upgrading/training of workers, acquiring supply sources, increasing capacity, forming strategic alliances, as well as using an outsourcing strategy are other prerequisites enhancing supply chain quality to gain competitive advantage and offer high customer satisfaction (Kearney, 1994; 
Sum, Teo, \& Kwan-kee, 2001). Effective business design and execution depends on how technology is used to deliver services faster, cheaper, and with better quality than competitors (Nickles, Mueller, \& Takacs, 1998; Coyle, Bradi, \& Langley, 2003; Salmela \& Lukka, 2004).

Another source of a competitive advantage is the SMEs ability to differentiate itself in the eyes of specific customers and in the market in general. Being more responsive to ever-changing customer demands, being able to reduce lead times through efficient supply chain processes, being able to reduce time in design and manufacturing processes and being able to introduce new products faster than competitors are all elements that reduce cycle time (Hugo, Babenhorst-Weiss, \& Van Rooyen, 2002).

\section{THEORETICAL FRAMEWORK AND HYPOTHESES}

Drawing from the literature on supply chain management (SCM) and business performance, a conceptual model is developed as shown in Figure 1. The model consists of five constructs, that is, three predictor variableseconomies of scale, organizational structure, and technological advancement, one mediating variable-SCM implementation, and one outcome variable-SME business performance. The model argues that SCM implementation by SMEs positively influences their business performance and the influence is predicted by economies of scale, organizational structure, and technological advancement.

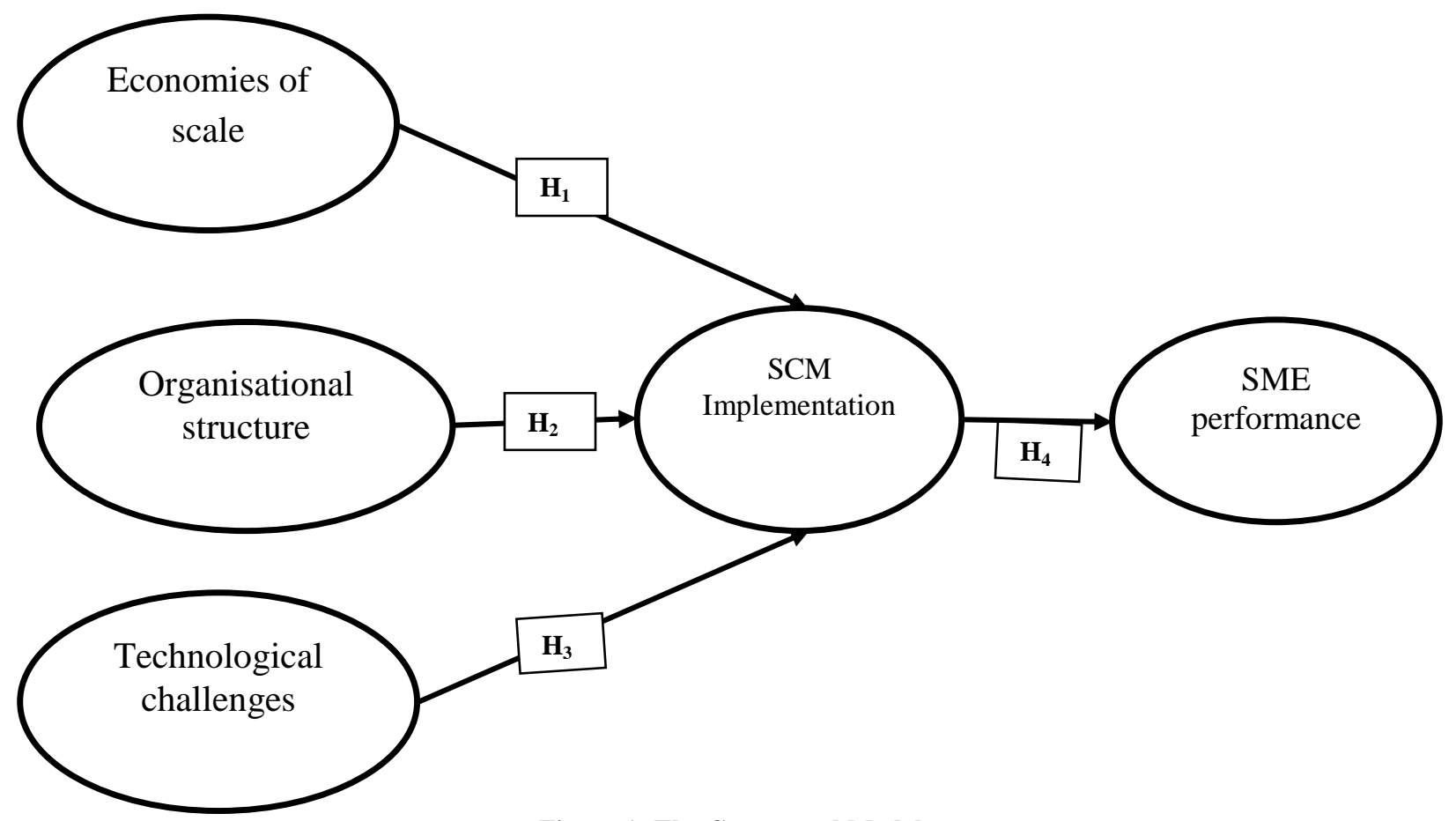

Figure 1: The Conceptual Model

\section{Economies of Scale and Supply Chain Implementation}

Economies of scale are when businesses expand business operations efficiency (Ferguson \& Hansson, 2013; Beijnen \& Bolt, 2009). This expansion may be due to changes in technology, change in increasing customers' demands, and so on (Xue, Ray, \& Sambamurthy, 2013). As companies expand in their business strategies, production units increase thereby gaining competitive advantage and lowering costs (Verhoef \& Lemon, 2013). The growing competitive environment is mainly based on agile supply chain systems through information technology, knowledge sharing and intellectual capital (Merali, Papadopoulos, \& Nadkarni, 2012; Wang \& Wang, 2012). It therefore means that organisations that have the capacity to deliver fast and also have the ability to raise productivity are those that are likely to gain a competitive advantage over the others. In this technology-based competitive 
environment, SMEs may not have the financial ability and the capacity that the market requires to gain the economies of scale resulting from deficiencies in business processes (Stratton \& Warburton, 2003).

$\mathbf{H}_{1}$ : Economies of scale (non-existent) for SMEs have a direct negative impact supply chain implementation.

\section{Organisational Structure and Supply Chain Implementation}

The organisational structure of SMEs business operations may have an effect on the successful implementation of supply chain strategies, particularly as they have a lesser hierarchical structure than larger organisations (Nicolescu, 2009). It therefore means that apart from other factors such as finance, education, skills, and others that hinder SMEs' supply chain implementation, organisational structure such as management, employees, and trade unions, availability or lack of human resources (labour, finance, and material), administrative intensity, technical knowledge resources, managerial attitude toward change, professionalism, functional differentiation, and specialisation are important in the implementation of SCM (Laforet, 2013). This study proposed that:

H2: Organisational structure (non-functional) within SMEs has a direct negative impact on supply chain implementation.

\section{Technology Integration and Supply Chain Implementation}

With the increasing competitive pressure among business as a result of external pressure from customers and competing organisations, supply chain technology integration can be the key to overcoming and gaining competitive advantages. Information and technology integration in supply chain management is beneficial to organisational performance. According to Harland, Caldwell, Powell, and Zheng (2007), "lack of strategic alignment of information technology; lack of awareness of potential benefits of supply chain technology and the lack of motivation are the main barriers to supply chain information integration among SMEs."

Information technology is regarded as one of the most valuable assets to assist management in decisionmaking (Madria, 2001). The information and communication technology provides the opportunity for small firms to improve their competitiveness and thereby enhancing business performance (Yoon, 2001). According to Chapman, Moore, and Thompson (2000), the use of information technology has been found to improve business competitiveness, with the internet providing the opportunity for SMEs to compete on equal terms with LEs. For example e-mail and the World Wide Web present such opportunities for SMEs. This study therefore proposes that:

H3: Technological challenges within SMEs has a direct negative impact on supply chain implementation.

\section{Supply Chain Management Implementation and SMEs Performance}

Formulation and implementation of supply chain strategy involves aligning growth strategies, logistics strategies, turnaround strategies, and divestment strategies (Wright, Kroll, \& Parnell 1998). Supply chain includes everything from the moment a product or service needs to be manufactured, through to incoming raw materials management, production, and finished goods storage, delivery to customer, and after sales service (Day, 1998). Supply chain is concerned with the profitable movement/transfer of information and materials into the organisation (time-based activity), through it, and out to customers (Hugo et al., 2002; Coyle et al., 2003; Ballou, 2004). Therefore, SMEs should determine the role of supply chain objectives within their business objectives because it is a strategy that can affect other functions in the organisation (Day, 1998).

Just as supply chain strategy formulation and implementation is not optional for larger organisations it is also not optional for SMEs. SMEs should have a formal supply chain strategy that will help them make strategic choices through business processes and operational activities (Rwigema, 2006). Being able to formulate and implement supply chain objectives within the SMEs business processes will help SMEs to be sustainable and outperform their competitors. This study therefore proposes that:

H4: Supply chain management implementation has a positive impact on SMEs business performance. 


\section{METHODOLOGY}

This study adopted a quantitative approach to establish the relationship between three key components of supply chain implementation and the business performance for SMEs. The approach was deemed appropriate as it enabled the researchers to objectively test and confirm the hypotheses, and to explain the impact of SCM on business performance.

\section{Instrument and Data Collection}

The data collection process involved SMEs operating within Vaal Triangle region, a highly industrialised area of Gauteng, South Africa. Due to the nature of the research, the targeted research participants were the SME managers and owner-managers. In particular, SME owners or officials who occupied senior management positions were interviewed. This was done to ensure the relevance of the data in evaluating the firms' SCM implementation and business performance. Face to face, paper, and pencil type interviews were done by the researchers with the help of trained interviewers. A structured questionnaire comprising five research constructs was used in line with the work of Pushpakumari and Watanabe (2009), with necessary modifications made in order to fit the current research context and purpose. The questionnaire began with the demographic information section which also incorporated the business characteristics such as, number of years in business, number of employees, and the type of industry to which the business belongs. This data was needed to establish a detailed profile for the sample. The sections B to F were on a 5-point Lickert-type-scale covering the questions relating to the five annotated constructs (economies of scale, organizational structure, technological integration, SCM implementation, and SME business performance). A total of 249 usable questionnaires were retrieved for the final run of data analysis.

\section{DATA ANALYSIS}

\section{Respondent Profile}

The data reported in Table 1 indicates that $55.4 \%(\mathrm{n}=138)$ of the participating SMEs employed less than 20 workers each, while $32.5 \%(n=81)$ of the SMEs had a workforce between $21-50$ employees and $12.1 \%(n=30)$ of them had between 51-100 employees. Regarding the gender of the participants, $63.5 \%(n=158)$ were male while the remainder $36.5 \%(\mathrm{n}=91)$ were female. The majority of the surveyed SMEs operate within the services industry as reported in the table $(55.4 \%, \mathrm{n}=138)$. The study also reports that the majority of the participants $(73.5 \%, \mathrm{n}=$ 183 ) belong to the age group between 31 and 60 years.

Table 1: Profile of Sample Characteristics

\begin{tabular}{|l|c|c||c|c|c|}
\hline \multicolumn{1}{|c|}{ Gender } & Frequency & Percentage & Number of Employees & Frequency & Percentage \\
\hline Male & 158 & $63.5 \%$ & $\leqq 20$ & 138 & $55.4 \%$ \\
\hline Female & 91 & $36.5 \%$ & $21-50$ & 81 & $32.5 \%$ \\
\hline & & & $\geqq 51$ & 30 & $12.1 \%$ \\
\hline Total & 249 & $100 \%$ & Total & 249 & $100 \%$ \\
\hline \multicolumn{1}{|c|}{ Age } & Frequency & Percentage & Industry & Frequency & Percentage \\
\hline$\leqq 30$ & 43 & $17.3 \%$ & & & 111 \\
\hline $31-60$ & 183 & $73.5 \%$ & Manufacturing & 138 & $54.6 \%$ \\
\hline$\geqq 60$ & 23 & $9.24 \%$ & Service & 249 & $100 \%$ \\
\hline Total & 249 & $100 \%$ & Total & & \\
\hline Marital Status & Frequency & Percentage & & & \\
\hline Married & 141 & $56.6 \%$ & & & \\
\hline Single & 108 & $43.4 \%$ & & & \\
\hline Total & 249 & $100 \%$ & & & \\
\hline
\end{tabular}

\section{Validity and Reliability}

Confirmatory factor analysis (CFA) was performed to examine scale accuracy of the multiple-item construct measures in AMOS version 5. First, a confirmatory factor analysis model that includes the five research constructs was assessed to check the model fit. The overall model statistics indicate that the ratio of chi-square 
$(\mathrm{CMIN}=599.763)$ to degrees of freedom $(\mathrm{DF}=231)$; i.e., $\left(\chi^{2} / \mathrm{df}\right)=2.596$, the goodness-of-fit-index $(\mathrm{GFI})$, the comparative-fit-index (CFI), the incremental fit index (IFI), the relative fit index (RFI), the normed fit index (NFI), and the root mean square error of approximation (RMSEA) are 0.898, 0.879, 0.899, 0.861, 0.881, and 0.229, respectively. All these measures are considered statistically significant and therefore, confirming a robust and acceptable model fit (Bentler, 1990).

Table 2: Accuracy Analysis Statistics

\begin{tabular}{|c|c|c|c|c|c|c|c|c|c|c|}
\hline \multirow{2}{*}{\multicolumn{2}{|c|}{$\begin{array}{l}\text { Research } \\
\text { Construct }\end{array}$}} & \multicolumn{4}{|c|}{ Descriptive Statistics } & \multicolumn{2}{|c|}{ Cronbach's Test } & \multirow{2}{*}{$\begin{array}{c}\text { C.R. } \\
\text { Value }\end{array}$} & \multirow{2}{*}{$\begin{array}{c}\text { AVE } \\
\text { Value }\end{array}$} & \multirow{2}{*}{$\begin{array}{c}\text { Factor } \\
\text { Loading }\end{array}$} \\
\hline & & \multicolumn{2}{|c|}{ Mean Value } & \multicolumn{2}{|c|}{ Standard Deviation } & \multirow{2}{*}{$\begin{array}{c}\text { Item-Total } \\
0.851 \\
\end{array}$} & \multirow[t]{2}{*}{$\alpha$ value } & & & \\
\hline \multirow{11}{*}{ SCMi } & SCMi1 & 3.615 & \multirow{11}{*}{3.117} & 0.973 & \multirow{11}{*}{0.846} & & & \multirow{11}{*}{0.902} & \multirow{11}{*}{0.829} & 0.923 \\
\hline & SCMi2 & 3.595 & & 0.924 & & 0.856 & \multirow{10}{*}{0.913} & & & 0.901 \\
\hline & SCMi3 & 3.360 & & 0.901 & & 0.872 & & & & 0.893 \\
\hline & SCMi4 & 3.148 & & 0.913 & & 0.861 & & & & 0.839 \\
\hline & SCMi5 & 2.915 & & 0.903 & & 0.859 & & & & 0.831 \\
\hline & SCMi6 & 2.895 & & 0.889 & & 0.861 & & & & 0.809 \\
\hline & SCMi7 & 2.760 & & 0.909 & & 0.865 & & & & 0.792 \\
\hline & SCMi8 & 2.748 & & 0.893 & & 0.866 & & & & 0.791 \\
\hline & SCMi9 & 2.695 & & 0.877 & & 0.864 & & & & 0.733 \\
\hline & SCMi10 & 2.654 & & 0.888 & & 0.863 & & & & 0.694 \\
\hline & SCMi11 & 2.615 & & 0.898 & & 0.874 & & & & 0.678 \\
\hline \multirow{4}{*}{ EoSc } & EoSc1 & 2.998 & \multirow{4}{*}{2.879} & 0.908 & \multirow{4}{*}{0.882} & 0.880 & \multirow{4}{*}{0.901} & \multirow{4}{*}{0.900} & \multirow{4}{*}{0.889} & 0.903 \\
\hline & EoSc2 & 2.895 & & 0.919 & & 0.874 & & & & 0.897 \\
\hline & EoSc3 & 2.885 & & 0.914 & & 0.884 & & & & 0.799 \\
\hline & EoSc4 & 2.860 & & 0.906 & & 0.882 & & & & 0.796 \\
\hline \multirow{5}{*}{ OrgS } & OrgS1 & 3.648 & \multirow{5}{*}{3.006} & 0.909 & \multirow{5}{*}{0.892} & 0.889 & \multirow{5}{*}{0.899} & \multirow{5}{*}{0.889} & \multirow{5}{*}{0.911} & 0.897 \\
\hline & OrgS2 & 3.415 & & 0.892 & & 0.884 & & & & 0.808 \\
\hline & OrgS3 & 3.195 & & 0.922 & & 0.894 & & & & 0.799 \\
\hline & OrgS4 & 2.960 & & 0.923 & & 0.879 & & & & 0.798 \\
\hline & OrgS5 & 2.948 & & 0.9630 & & 0.839 & & & & 0.689 \\
\hline \multirow{4}{*}{$\mathrm{TecC}$} & TecC1 & 2.915 & & 0.781 & & 0.778 & & & & 0.899 \\
\hline & TecC2 & 2.892 & & 0.858 & 0737 & 0.741 & & & & 0.859 \\
\hline & TecC3 & 2.788 & 2.119 & 0.893 & 0.131 & 0.783 & 0.908 & 0.903 & 0.139 & 0.843 \\
\hline & TecC4 & 2.627 & & 0.928 & & 0.789 & & & & 0.787 \\
\hline & BusP1 & 3.948 & & 0.781 & & 0.778 & & & & 0.929 \\
\hline & BusP2 & 3.815 & & 0.858 & & 0.741 & & & & 0.905 \\
\hline BusP & BusP3 & 3.795 & 3.819 & 0.893 & 0.131 & 0.783 & 0.901 & 0.919 & 0.135 & 0.893 \\
\hline & BusP4 & 3.760 & & 0.928 & & 0.789 & & & & 0.871 \\
\hline
\end{tabular}

Note: $\mathrm{EoSc}=$ Economies of scale; OrgS = Organisational structure; TecC = Technological challenges; SCMi = Supply chain implementation; BusP = Business Performance; C.R.: Composite Reliability; AVE: Average Variance Reliability; * Scores: $1=$ Strongly Disagree; $3=$ Neutral; 5 $=$ Strongly Agree. $*$ significance level: $* * * p<0.01$. Measurement CFA model fit: Structural Model Fits: $\chi^{2} / \mathrm{df}=2.596$; GFI $=0.898 ; \mathrm{CFI}=$ $0.879 ; \mathrm{IFI}=0.899 ; \mathrm{RFI}=0.961 ; \mathrm{NFI}=0.881 ;$ and $\mathrm{RMSEA}=0.229$.

As shown in Table 2, the composite reliabilities are above 0.9 and at values all above 0.7 , the average variances extracted (AVE) exceed the 0.5 benchmark (Fornell \& Larcker, 1981). In addition, all of the coefficient alpha values exceeded the threshold value of 0.7 and all the factor loadings significantly above the recommended thresh-hold of 0.5 (Malhotra, 2010). These results provide support for an acceptable degree of internal consistency between the corresponding indicators that satisfy convergent validity (Chinomona, 2012).

Table 3: Chi-Square Differences in All Two-Factor CFA Tests $\left(\Delta \chi^{2}(1)\right)$

\begin{tabular}{l|c|c|c|c|c}
\hline \multicolumn{1}{c|}{ Research Constructs } & EoSc & OrgS & TecC & SCMi & BusP \\
\hline Economies of Scale (EoSc) & 1.000 & 52.031 & 60.987 & 46.354 & 43.987 \\
\hline Organisational Structure (OrgS) & & 1.000 & 90.227 & 57.034 & 45.173 \\
\hline Technological Challenges (TecC) & & & 1.000 & 54.532 & 46.987 \\
\hline Supply Chain Implementation (SCMi) & & & & 1.000 & 51.859 \\
\hline Business Performance (BusP) & & & & & 1.000 \\
\hline
\end{tabular}

Note: All figures significant at least at a significance level of 0.01 . 
To investigate the distinctiveness of constructs, discriminant validity test compared the variance-extracted estimates of the measurements with the square of the parameter estimate between the measurements (Fornell \& Larcker, 1981). As illustrated in Table 3, this study further ascertain discriminant validity the researchers performed a chi-squire difference (constrained-unconstrained) in all two-factor (i.e., any paired latent constructs) CFA tests (which restricted the factor inter-correlations to unity) (Anderson \& Gerbing, 1988). As such, all pairs of the constructs and the two-factor CFA tests results revealed an adequate level of discriminant validity. Overall, the two approaches used to check discriminant validity suggest that discriminant validities exist. Therefore, the results supported the discriminant validity of constructs.

\section{Structural Equation Modeling}

Using LISREL 8.8 statistical software program, structural equation modelling (SEM) was run to test the validity of the proposed model and the hypotheses. The estimated model is presented in Table 4, illustrating the direction and magnitude of the impact of the standardized path coefficients. The overall structural equation model assessment also showed acceptable fit of $\chi 2 / \mathrm{df}=2.596$; $\mathrm{GFI}=0.898 ; \mathrm{CFI}=0.879 ; \mathrm{IFI}=0.899 ; \mathrm{RFI}=0.961 ; \mathrm{NFI}=$ 0.881 ; and RMSEA $=0.229$. As explained by these indices, the model's fit exhibits satisfactory parameters, thereby providing a good basis for testing the hypothesized paths. The parameter estimates of the structural model showed the direct effects of one construct on the other. The significant coefficients at these levels of alpha thus reveal significant relationships among latent constructs (Chinomona, 2012).

These results in Table 4 provided support for the entire proposed four research hypotheses. The path coefficients for $\mathrm{H}_{1}, \mathrm{H}_{2}, \mathrm{H}_{3}$, and $\mathrm{H}_{4}$ are $-0.639,-0.143,-0.389$, and +0.231 respectively. All hypothesis coefficients are significant at a confidence level ( $p$-value) of 0.001 .

Table 4: Results of Structural Equation Model Analysis

\begin{tabular}{|l|c|c|c|c|c|}
\hline \multicolumn{1}{|c|}{ Hypotheses } & \multicolumn{3}{c|}{ Path } & \multicolumn{1}{c|}{$\begin{array}{c}\text { Estimate } \\
\text { Coefficients }\end{array}$} & Result \\
\hline $\begin{array}{l}\mathrm{H}_{1}: \text { Economies of scale (non-existent) for SMEs have a } \\
\text { negative direct impact on supply chain implementation. }\end{array}$ & SCMi & $<--$ & EoSc & $-0.639^{\mathrm{b}}$ & Accepted \\
\hline $\begin{array}{l}\mathrm{H}_{2}: \text { Organisational structures (non-functional) within } \\
\text { SMEs have a negative direct impact on supply chain } \\
\text { implementation. }\end{array}$ & SCMi & $<-$ & OrgS & $-0.143^{\mathrm{b}}$ & Accepted \\
\hline $\begin{array}{l}\mathrm{H}_{3}: \text { Technological challenges within SMEs have a } \\
\text { negative direct impact on supply chain implementation. }\end{array}$ & SCMi & $<--$ & $\mathrm{TecC}$ & $-0.389^{\mathrm{c}}$ & Accepted \\
\hline $\begin{array}{l}\mathrm{H}_{4}: \text { Supply chain management implementation has a } \\
\text { positive impact on SMEs business performance. }\end{array}$ & BusP & $<--$ & SCMi & $+0.231^{\mathrm{b}}$ & Accepted \\
\hline
\end{tabular}

Structural Model Fits: $\chi 2 / \mathrm{df}=2.596 ;$ GFI $=0.898 ; \mathrm{CFI}=0.879 ; \mathrm{IFI}=0.899 ; \mathrm{RFI}=0.961 ; \mathrm{NFI}=0.881$; and RMSEA $=0.229$. ${ }^{a}$ Significance Level $p<0.05 ;{ }^{\mathrm{b}}$ Significance Level $p<0.01$; ${ }^{\mathrm{C}}$ Significance Level $p<0.001$.

\section{DISCUSSION AND CONCLUSION}

This current study sought to examine the impact of non-existent economies of scale (EoSc), non-functional organizational structures (OrgS), and technological structures (TecC) on the implementation of supply chain management (SCMi), in order to provide a theoretical grounding for the conceptualized framework which proposed that the resultant impact of these components on SCMi indirectly influences business performance (BusP) for SMEs. Specifically, the current study postulated four hypotheses and in order to test these hypotheses data were collected from SMEs in South Africa. The empirical results supported all the postulated research hypotheses in a significant way.

Drawing from the findings of this research, both lack of economies of scale (-0.639) and technological challenges $(-0.389)$ have stronger negative influence on SMEs' capacity to implement supply chain management than does organizational structure (-0.143). The findings concur with Mentzer, Dewitt, Keebler, Min, Nix, Smith, and Zacharia (2001) who argue that supply chain management is not well developed in the majority of SMEs due to their size and mean levels of investment in technology. Mentzer, Flint, and Hult (2001) state that "effective supply chain management and active participation of SMEs in supply chain strategy operations depends on the perspective 
that they adopt while making strategic decisions." In effect, SMEs should not only make deliberate choices on what firm size suits them, but also on what the appropriate structure for it should be, given the role they want to play in their supply chain strategy operations.

The findings in this study also confirm the importance of technology in contemporary business operations and supply chain technology integration. Yusuf, Guasekaran, Adeleye, and Sivayoganathan (2004) refer to it as 'agile supply chain'; the ability of organisations to respond quickly to market changes, ability to be flexible in implementing recent supply chain technology, as well as the ability to cope with competition. One surprise in the current study is that supply chain implementation revealed a weak positive influence (0.231) on business performance of SMEs. Perhaps, since there is a weak relationship between supply chain implementation and business performance, it might imply that both lack of economies of scale and technological challenges are indirectly negatively influencing SMEs business performance through impeding the implementation of supply chain management. In line with Teece, Pisano, and Shuen (1997), path dependencies might partly explain the weak relation between these two components.

\section{IMPLICATIONS OF THE STUDY}

In South Africa, the SMEs sector is deemed the engine of economic growth and vehicle for employment generation. The current study therefore has some useful implications for both academicians and practitioners; practically contributing to the interactive small business literature and practice, particularly on supply chain implementation and SMEs business performance.

On the academic side, a contribution regarding the impact of technological challenges, lack of structure, and operational size on business performance from an often most neglected SMEs sector in a developing country of Southern Africa is made to the interactive marketing literature. This study adds value to the knowledge of the perceived benefits of implementing supply chain management activities by SMEs in South Africa. Apart from the perceived benefits, the study also shows the challenges faced by SMEs in implementing supply chain management. This will help other researchers to determine which area of supply chain management to focus on when developing interventions with supply chain activities in SMEs.

On the practitioners' side, the prominence of supply chain management as a precursor to improved business performance is confirmed. Moreover, the adoption of new technologies might require the SMEs to also adjust their organizational structure and improve employees and management skills in order to achieve high levels of business performance. It is imperative that the SMEs accordingly adjust for instance, their organizational structure, human capital skills, operational strategies and technologies in tandem with the challenges that come with the processes, and implementation of supply chain management. Given that improved business performance imply high revenue and profitability for SMEs, indeed managers and business owners that have not effectively utilized supply chain systems yet, can increase their firms' profitability by integrating technology and invest to enhance supply chain capabilities.

In a nutshell, this study submits that the SME owners and their managers can successfully improve their business performance by exploiting their supply chain management strategies, technology adoption, and restructuring their operations. Eventually, a successful supply chain management system is expected to boost business performance and generate more revenue for the SMEs, hence their profitability and survival.

\section{LIMITATIONS AND FUTURE RESEARCH}

Although the study makes significant contributions to both academia and practice, it bears some limitations that provide avenues for future research directions. The study used cross-sectional data and it is expected that the results might differ if a larger sample covering the other regions of South Africa was used. A richer understanding of the relationships between this study's research constructs might be expected if longitudinal data is utilized. Therefore, future studies might consider this research direction. The study investigated only SMEs, the results could differ if research would be carried out on micro organizations or larger firms. Further research should cover SMEs in the whole of South Africa, so as to provide a clearer picture of the extent of implementation, challenges, and 
benefits country-wide. First, the data were gathered from the SME owners and managerial staff members. This can have influence on the method bias in the results. Therefore, future survey researches should attempt to incorporate secondary source data in order to provide further insight into the impact of supply chain implementation and business performance. Future researches might consider investigating the possible mediating influence of other variables such as work experience, age, or gender in this 'supply chain management' and 'business performance' relationship.

\section{AUTHOR INFORMATION}

Dr. Job Dubihlela is senior lecturer in the Faculty of Management Sciences at Vaal University of Technology, South Africa. E-mail: job@vut.ac.za (Corresponding author)

Ms. Osayuwamen Omoruyi is a lecturer at Vaal University of Technology, South Africa in the department of Logistics within the Faculty of Management Sciences.

\section{REFERENCES}

1. Agapiou, A., Clausen, L. E., Flanagan, R., \& Norman, G. (1998). The role of logistics in the materials flow control process. Construction Management and Economics, 16, 131-137.

2. Ballou, R. H. (2004). Business logistics/supply chain management: Planning, organising, and controlling the supply chain (4th ed.). Upper Saddle River, NJ: Prentice Hall.

3. Beijnen, C., \& Bolt, W. (2009). Size matters: Economies of scale in European payments processing. Journal of Banking \& Finance, 33, 203-210.

4. Bienstock, C. C., Royne, M. B., Sherrell, D., \& Stafford, T. F. (2007). An expanded model of logistics service quality: Incorporating logistics information technology. International Journal of Production Economics, 133, 205-222.

5. Burns, P. (2005). Corporate entrepreneurship: Building an SME organisation. NY: Palgrave Macmillan.

6. Chan, J. W. K., Burns, N. D., \& Yung, K. L. (2000). Environment-strategy fit: A study of Hong Kong manufacturing logistics. Logistics Information Management, 13(5), 286-300.

7. Chapman, P., Moore, M. J., \& Thompson, D. (2000). Building internet capabilities in SMEs. Journal of Logistics Information Management, 13(6), 353-361.

8. Chow, W. S., \& Lui, K. H. (2001). Discriminating factors of information systems function performance in Hong Kong firms practicing TQM. International Journal of Operation \& Production Management, 21(5/6), 749-771.

9. Coyle, J. J., Bardi, E. J., \& Langley C. J. (2003). The management of business logistics: A supply chain perspective (7th ed.). Canada: Thomson Learning.

10. Day, A. (1998). Getting logistics into the boardroom. International Journal of Physical Distribution and Logistics Management, 28(10), 661-665.

11. Drew, S. A. W., \& Smith, P. A. C. (1998). The new logistics management: Transformation through organisational learning. International Journal of Physical Distribution and Logistics Management, 28(10), 666-681.

12. Ferguson, R., \& Hansson, H. (2013). Expand or exist? Strategic decisions in milk production. Livestock Science, 155, 415-423.

13. Halley, A., \& Guilhon, A. (1997). Logistics behaviour of small enterprises: Performance, strategy and definition. International Journal of Physical Distribution \& Logistics Management, 27(8), 475-495.

14. Harland, C. M., Caldwell, N. D., Powell, P., \& Zheng, J. (2007). Barriers to supply chains information integration: SMEs adrift of eLands. Journal of Operations Management, 25, 1234-1254.

15. Hugo, W. M. J., Babenhorst-Weiss, J. A., \& Van rooyen, D. C. (2002). Purchasing and supply management (4th ed.). Pretoria: Van Schaik Publishers.

16. Jesselyn, M. (2006). Analysing the macro-environment. In L. Louw \& P. Venter (ed.), Strategic management: Winning in the Southern African workplace (pp. 77-112). Cape Town: Oxford.

17. Kisalvi, V. (2002). The Entrepreneur's character, life issues and strategy making: A field study. Journal of Business Venturing, 17(1), 489-518.

18. Kotler, P. (1997). Marketing management (9th ed.). Englewood-Cliffs: Prentice Hall. 
19. Laforet, S. (2013). Organisational innovation outcomes in SMEs: Effects of age, size and sector. Journal of World Business, 48, 490-502.

20. Lasserre, F. (2004). Logistics and the internet: Transportation and location issues are crucial in the logistics chain. Journal of Transport Geography, 12, 73-84.

21. Levey, M., \& Powell, P. (2005). Strategies for growth in SMEs: the roles of information and information systems. Burlington: Oxford.

22. Li, P. C., \& Lin, B. W. (2006). Building global logistics competence with Chinese OEM suppliers. Technology in Society, 28, 333-348.

23. Madria, S. K. (2001). Data warehousing. Data \& Knowledge Engineering, 39, 215-217.

24. Mason, S. J., Ribera, P. M., Farris, J. A., \& Kirk, R. G. (2003). Integrating the warehousing and transportation functions. Transportation Research Part E, 39, 141-159.

25. Mentzer, J. T., Dewitt, W., Keebler, J. S., Min, S., Nix, W. N., Smith C. D., \& Zacharia, Z. G. (2001). Defining supply chain management. Journal of Business Logistics, 22(2), 1-25.

26. Mentzer, J. T., Flint, D. J., \& Hult, T. M. (2001). Logistics service quality as a segment-customised process. Journal of Marketing, 65, 82-104.

27. Merali, Y., Papadopoulos, T., \& Nadkarni, T. (2012). Information system strategy: Past, present, future? Journal of Strategic Information Systems, 21, 125-153.

28. Molz, R. (1998). Steps to strategic management: A guide for entrepreneurs. NY: Word Ware Publishing Inc.

29. Nickles, T., Mueller, J., \& Takacs T. (1998). Strategy, information technology and the supply chain. Managing information technology for success, not just survival. In J. Gattorna (ed.), Strategic supply chain management: Best practice in supply chain management (pp. 494-508). Brookfield, VT: Gower.

30. Nicolescu, O. (2009). Main features of SMEs organisation system. Review of International Comparative Management, 10(3), 405-413.

31. Perks, K., \& Bouncken R. (2004, December 4). Home page. University of Brighton. Retrieved 04/11/2013 from http://www.strategicmanagement/perks.html

32. Robbins, S. P., \& Coulter, M. (2005). Management (8th ed.). NY: Pearson prentice Hall.

33. Robinson, P. (1994). Strategic management: Formulation, implementation and control (15 ${ }^{\text {th }}$ ed.). NY: McGraw-Hill.

34. Rwigema, H. B. (2006). Corporate level strategy: The quest for shareholder value. In L. Louw \& P. Venter (ed.), Strategic management: Winning in the Southern African workplace (pp. 208-242). Cape Town: Oxford.

35. Salmela, E., \& Lukka, A. (2004).Value added logistics in supply and demand chains. (A research report 153 for the E-Business between global company and its local SMEs supplier network 2004). Lappeenrant University of Technology.

36. Saura, I. G., Frances, D. S., Contri, G. B., \& Blasco, M. F. (2008). Logistics service quality: A new way to loyalty. Industrial Management \& Data Systems, 108(5), 650-668.

37. Stratton, R., \& Warburton, R. D. H. (2003). The strategic integration of agile and learn supply. International Journal of Production Economics, 85, 183-198.

38. Sum, C. C., Teo, C. B., \& Kwan-kee, N. G. (2001). Strategic logistics management in Singapore. International Journal of Operations and Production Management, 12(9), 1239-1260.

39. Van der vorst, J. G. A. J., Beulens, A. J. M., \& Van beek, P. (2005). Innovations in logistics and ICT in food supply chain networks. In W. M. F. Jongen \& M. T. G. Meulenberg (ed.). Innovation in agric-food system (pp. 245-292). Wageningen: Wageningen Academic Publishers.

40. Verhoef, P. C., \& Lemon, K. N. (2013). Successful customer value management: Key lessons and emerging trends. European Management Journal, 31, 1-15.

41. Wang, Z., \& Wang, N. (2012). Knowledge sharing, innovation and firm performance. Expert System with Applications, 39, 8899-8908.

42. Wright, P., Kroll, M., \& Parnell, J. (1998). Strategic management: concepts and cases (4th ed.). NY: Prentice Hall.

43. Xue, L., Ray, G., \& Sambamurthy, V. (2013). The impact of supply chain electronic integration on customer service performance. Journal of Operations management, 829, 1-13.

44. Yoon, H. D. (2001). The logistical competitiveness of SMEs and global supply chain. Journal of Operational Research, 25, 163-170. 
45. Yusuf, Y. Y., Guasekaran, A., Adeleye, E. O., \& Sivayoganathan, K. (2004). Agile supply chain capabilities: Determinants of competitive objectives. European Journal of Operational Research, 159, 379392.

46. Zacharia, Z. G., \& Mentzer, J. T. (2007). Role of logistics in new product development. Journal of Business Logistics, 28(1), 83-110. 


\section{NOTES}

